\title{
From Field Data to Ecosystem Services Maps: Using Regressions for the Case of Deforested Areas Within the Amazon
}

\section{Journal Article}

Author(s):

Le Clec'h, Solen; Jégou, Nicolas; Decaëns, Thibaud; Dufour, Simon; Grimaldi, Michel; Oszwald, Johan

Publication date:

2018-03

Permanent link:

https://doi.org/10.3929/ethz-b-000181724

Rights / license:

In Copyright - Non-Commercial Use Permitted

Originally published in:

Ecosystems 21(2), https://doi.org/10.1007/s10021-017-0145-9 


\section{From field data to ecosystem services maps: using regressions for the case of deforested areas within the Amazon}

Short version: Statistical methods to map ecosystem services

Le Clec'h Solen ${ }^{1}$, Jégou Nicolas ${ }^{3}$, Decaens Thibaud ${ }^{4}$, Dufour Simon ${ }^{1}$, Grimaldi Michel ${ }^{5}$, Oszwald Johan $^{1}$

1Laboratoire LETG Rennes - COSTEL (UMR CNRS 6554), Université Européenne de Bretagne, Rennes 2, France; 2Agricultural Economics and Policy Group, ETH Zurich, Zurich, Switzerland;

3Laboratoire IRMAR (UMR CNRS 6625), Université Européenne de Bretagne, Rennes 2, France;

4Centre d'Ecologie Fonctionnelle et Evolutive, UMR 5175 CNRS/Univ of Montpellier/Univ of Montpellier 3/EPHE/SupAgro Montpellier/INRA/IRD, 1919 Route de Mende, 34293 Montpellier Cedex 5, France;

5UMR 242 iEES-Paris - Centre IRD France-Nord, Institut de Recherche pour le Développement (IRD), Bondy, France

Abstract: Quantifying and mapping ecosystem services (ES) is seen as one way to improve decision making and land management to better integrate environmental issues. This study aimed to characterize ES supply in deforestation context where an improvement of scientific knowledge should help reaching a more efficient environmental management. For three case studies in the Brazilian Amazon impacted by deforestation, seven indicators of potential ES supply were mapped at a spatial resolution of $30 \times 30 \mathrm{~m}$ : biodiversity index (indicator of food web support); richness of pollinators (pollination); index of soil chemical quality (support to production); water available for plants (water regulation); soil carbon stocks (support to production and climate regulation); rate of water infiltration into the soil (soil erosion control) and vegetation carbon stocks (climate regulation). To map these indicators, in situ measurements of ES for 135 sampling points and remote-sensing data were linked using regression methods. These methods were used to predict ES values and identify environmental factors that influence ES supply. The resulting maps help understanding the influence of environmental factors on ES spatial distribution within the sites. The analyses illustrate the influence of land-use changes on ES supply and the role of context effects due to the heterogeneity of the biophysical environment, the 
temporality of deforestation, and/or their diversified socio-political contexts. From a methodological viewpoint, the study highlights the importance of choices inherent in all cartographic practices and that need to be considered, especially in the context of rendering ES maps operational.

Keywords: ecosystem service indicators, biophysical processes, statistical model, regression, remote sensing, land cover, deforestation, Brazilian Amazon.

\section{Introduction}

Ecosystem services (ES) are the benefits humans obtain from ecosystems (Daily, 1997; MEA, 2005). Since the publication of the Millennium Ecosystem Assessment (MEA) in 2005, the concept of ES has become one of the new key concepts in environmental governance. Quantifying and mapping the ES, or indicators of their associated biophysical processes, is seen as one way to improve decision making and land management to better integrate biodiversity issues (Daily and Matson, 2008). Mapping ES should help policy makers target strategic areas, formulate new policies and/or evaluate impacts of previous policies (McInerny et al., 2014).

Since ES are intermediaries between the ecosystems that supply them and the society that receives them, it is hard to measure them directly. Therefore their assessment and mapping are mainly done through the definition of indicators. In our study, as we aim to quantify and map ES supply, we choose indicators of the biophysical processes. An indicator is a polysemic term 
(Heink and Kowarik, 2010) whose definition used in this paper is partly based on the one proposed by the OECD. It defines an indicator as a measure of an environmental phenomenon used to describe or assess environmental conditions or changes or to set environmental objectives (OECD, 2003). For example, one of the most commonly spatial indicators in the scientific literature on ES is carbon stock, allowing the apprehension of the service of regulation of the climate.

Methodological questions exist while mapping ES indicators (Grêt-Regamey et al., 2014; Schulp et al., 2014; Le Clec'h et al., 2016) as the interpolation and extrapolation of ES indicators rely on arbitrary choices, such as choices related to the methodology and the spatial scale of representation. The importance of spatial scales in environmental assessments is often emphasized (National Assessment of Climate Change, 2000), since each scalar level allows an analysis that is differentiated according to geographical characteristics and conditions both the type of input data and its accuracy. Pagella and Sinclair (2014) defined in this sense five categories of spatial scales: local, regional, national, supra-national and global, according the size and the main actors of the study area, among others.

For example, at the local scale, ES maps can be based on reliable estimates that take local characteristics into account. They present major methodological and operational challenges (Grêt-Regamey et al., 2014; Malinga et al., 2015). Thus, they enable precise distinction of areas where ES is high (hotspots - high supply of one or few ES) and low (coldspots) based on accurate datasets. These maps can also associate these areas with controlling factors, such as topographical variations or land-cover changes. In this way, local ES maps can help spatially target conservation and development activities and assess benefits and costs of alternative 
policies (Grêt-Regamey et al., 2014). Furthermore, they help transfer knowledge and information among many actors, especially farmers, who expect to visualize their land in a recognizable context (Pagella and Sinclair, 2014). At broader scales, ES maps provide an overview of general trends or the general state within a political and / or administrative entity at the scale of which decisions are made. Despite the issues associated to the local scale, few studies have mapped ES or their indicators at the local scale ${ }^{1}$. Following the criteria proposed by Pagella and Sinclair (2014), we decided to characterize our study sites as belonging to the local scale. Indeed, they cover less than $250 \mathrm{~km}^{2}$ and are relatively homogeneous in terms of climate, landscape and socioeconomic characteristics. As pointed out by Pagella and Sinclair (2014), our local-scaled maps can then be seen as a tool to help farmers since they could allow them to situate themselves in a familiar context and requires a set of spatial data at high or very high spatial resolution.

In addition to the scale related issues, questions about extrapolation and interpolation methods exist. Indeed, several ways exist to map ES indicators. Most studies attributing one ES value per land-cover type (Fisher et al., 2011) or on applying ecological (Nelson et al., 2009; Bai et al., 2012) or economic models (Naidoo et Ricketts, 2006; Busch et al., 2012). Less common ways are based on using complex models (e.g. ARIES model - Villa et al., 2009 ) or process-based models (e.g. InVEST- Sharp et al., 2014), developing participatory approaches (Sherrouse et al., 2011; Palomo et al., 2013, Darvill et Lindo, 2015) or applying statistical methods to extrapolate field data using remote sensing to a large region. Although statistical methods for mapping ES remain

${ }^{1}$ Only $15 \%$ of articles with an ES (indicator) map belonging to the scientific literature from 1990-2014 that can be found on the Web of Science by identifying the following keywords: "ecosystem* service*" AND mapping (or map*) OR "environmental* service*" AND mapping (or map*) OR “ecological* service*” AND mapping (or map)*). 
rare, they have high potential: they enable better understanding of ES supply and the factors that influence it, and they help predict values of ES indicators for an entire region. Moreover, they must be created with sampling data.

In this context, this study aimed to analyze and characterize ES supply in the context of deforestation where an improvement of scientific knowledge should help to understand the impacts of deforestation activities and to reach a more efficient environmental management (Théry, 2012). Our specific objectives were (1) to identify factors of control of several ES indicators and (2) to map these indicators and analyze the resulting maps to determine principal spatial components and structures of the landscape. To do so, we describe our use of statistical methods to map a relatively large set of ES indicators (a biodiversity index, richness of pollinators, a soil chemical quality index, water available for plants, soil carbon stocks, rate of water infiltration into the soil and vegetation carbon stocks). Most of the ES indicators mapped in this paper are rarely studied, possibly due to a lack of understanding about their issues by the scientific community or by stakeholders who order maps to be made. For instance, very few papers consider soil ecosystem services, in comparison with climate regulation service or services related to water supply (Dominati et al., 2010). Our statistical modelling is based on a dataset highly diversified in terms of addressed thematic areas (related to the site, vegetation and topography) and number of data. Indeed, ES are provided by biophysical processes or ecological functions whose functioning can be complex and, if ES are still often mapped from one data, such as a land use classification (eg Kienast et al., 2009), it seems essential to take into account a wide variety of information. This paper is thus based on the interpolation of field data points to an entire study site, via the use of data derived from remote sensing. We applied the method to 
three study sites in deforestation areas in the Brazilian Amazon. In this part of the world, deforestation processes occur through the implantation of deforestation fronts (Arnauld de Sartre, 2006), highly dynamic areas where deforestation occurs at a very high rate. These areas are subject to very strong tensions between environmental protection and economic development. Therefore, it is interesting to implement in this context the notion of ES whose ambition is to analyze these tensions. Moreover, as changes in these areas are intense and fast, the analyses of ES and their dynamics are very interesting and ES maps could be seen as a new tool to support environmental management in these areas.

The resulting maps were analyzed to determine the main spatial elements of the region and to understand the factors that controlled the ES indicators. In this way, as they are one simple way to represent biophysical processes and show variations in ES supply, maps of ES indicators enable better understanding of environmental challenges in the studied areas.

\section{Methods}

\subsection{General approach}

In a deforestation dynamics areas context, the study of ES supply is highly relevant because of the lack of regulations, public policies and environmental management. It should improve the understanding of environmental impacts of deforestation and help the evaluation of past and current public policies (or their absence) influence on ecosystems. 
The methodology was based on the implementation of a regression method to model various ES indicators from dataset obtained by satellite image processing. In other words, we tried to estimate for all the pixels of each study area values for seven ES indicators. As, this information was measured in situ and was known only at the sampling points, we applied a regression method as an extrapolation method. Doing that, the study followed three main steps.

- First, we identified a reliable statistical method to map each ES indicator. To do so, we implemented and compared for each indicator two regression methods (regression tree and linear regression). The method with the highest predictive capacity was used in the other steps.

- Next, we identified factors controlling each indicator of ES supply. To do so, we applied the variable selection procedure on each selected regression method to identify remote sensing data that impacted significantly the ES supply.

- Finally, we mapped each ES indicator and described its spatial distribution for the three study sites. To do so, the selected regression methods were used to predict new values from the significant remote sensing data.

\subsection{Study sites}

This paper studied three locations in the Brazilian Amazon rainforest in the state of Pará: Macaranduba, Pacajá and Palmares II (Figure 1). The Brazilian Amazon, like any forest, provides a large number of ES. Yet, large parts of the Amazon are dramatically threatened by deforestation and the dynamics of forest degradation (Evans et al., 2001; Fearnside, 2005; INPE-Prodes, 2014), especially in Pará State, which has one of the highest deforestation rates in the Amazon (1887 
$\mathrm{km}^{2}$ in 2014 - INPE-Prodes, 2014). With high deforestation rates and forest degradation, the Amazon presents significant challenges for creating effective environmental policies. In tropical forests, especially the Amazon, the ecological issues of biodiversity and ES are well known and documented (Metzger et al., 2006). As the largest tropical forest in the world, the Amazon has one of the highest levels of biodiversity and is considered an ES hotspot. At the same time, the Amazon has experienced several decades of significant deforestation, mainly for timber and cattle (Fearnside, 2008; Godar et al., 2012), even though rates have decreased in recent years (INPE-Prodes, 2014). According to the FAO, more than 100 million ha were deforested in tropical forests from 1996-2010 (FAO, 2012).

At nearly $1,25 \mathrm{~km}^{2}$, Pará is the second largest state in Brazil and includes the Amazon rainforest as part of its territory. In 2013, deforestation in Pará represented almost 50\% of all deforestation in Brazil. Deforestation, even partial, impacts the supply of ES highly. Environmental and agricultural policies and stakeholders need tools to evaluate, monitor and respond to these impacts.

Figure 1

Maçaranduba is a $220 \mathrm{~km}^{2}$ site belonging to the municipality of Nova Ipixuna. Located in a largely deforested area, it has been deforestation since the 1970s but the forest cover remains relatively well preserved. Pacajá is $175 \mathrm{~km}^{2}$ site, located about $60 \mathrm{~km}$ from the urban center. Deforestation from spontaneous colonization began in the 1990s and follows a track (Traverssão 338 south) perpendicular to the Trans-Amazon highway, called the "fishbone". Forest cover was 
still high (63\%) in 2007. Palmares II is an assentamento (settlement) of approximately $160 \mathrm{~km}^{2}$. it is located near the Carajas iron mine. Emblematic of agrarian reform, the site was divided into similar-sized lots, which fragmented the area.

\subsection{Data}

Two datasets were used to model ES indicators: field data (the response variable) and remotesensing data (explanatory variables).

\subsubsection{Field data: response variables}

Thus, seven ES indicators related to three groups: biodiversity (an index of biodiversity and species richness of pollinator moths - Sphingidae), biophysical soil processes (soil chemical quality, water available for plants, soil carbon stocks and rate of water infiltration into the soil) and vegetation structure (vegetation carbon stocks) were sampled (Table 1).

\section{Table 1}

These seven indicators were chosen for three main reasons: first, the study of each of them was relevant in a context of deforestation. Secondly, as they were provided from diversified biophysical processes and at different spatial scales, they were complementary to each other. Preliminary statistical analyses demonstrated that they are not auto-correlated. Thirdly, we chose 
to study indicators, such as vegetation and soil carbon stocks, biodiversity and pollinator richness, that were associated with ES that are frequently taken into account in scientific studies and in public policies, and indicators, such as water available for plants, are often understudied or forgotten. In other words, the issues of indicators from the first category are well known among the scientific and non scientific communities, whereas the issues of the others are not, or in a less extent. These indicators were statistically very heterogeneous (for instance, some are indexes, others are variables). However, this heterogeneity was not a problem for our analyses, since each indicator was study independently of the others.

All indicators were assessed using field data collected from 9 farms per site. These nine selected farms were representative of the differences in landscape and socio-economic characteristics of the farmers that are present on each of the sites. On each of the 27 farms, five sampling points were spaced equally along a transect corresponding to the longest diagonal of the farm or a northsouth axis. Transects intersected all major land covers in the region, including disturbed and intact forests, and had an average length of $1 \mathrm{~km}(\mathrm{std} . \mathrm{dev} . \approx 0)$. The distance among points was equal to $1 / 6$ of the transect length. Measurements and data collection took place in 2008 during four months (April-July) of the rainy season. The indicators were calculated as follows (for more details, see Grimaldi et al., 2014):

\section{Biodiversity index}

Despite historically strong links, the relationship between the notions of biodiversity and ES is far from being clear and the nature of these links is often controversial (Larrère and Larrère, 2015). In this study, biodiversity was considered an ES indicator because of its essential role in human 
well-being (MEA, 2005; Diaz et al., 2006). It indeed can be considered as an indicator of the food web support service.

Biodiversity was represented through the use of a standardized indicator of species richness which indicates the mean of several species richnesses for each of the 135 sampling points.

It was built from twelve groups of organisms that were sampled during field works: moths, birds, bees, fruit flies, ground spiders, ants, termites, earthworms, other soil macro-invertebrates, and lower, medium and higher strata of the vegetation. For each taxonomic group, the species composition and the number of individuals observed for each species were recorded. Groups of organisms were chosen for at least one these factors:

- their link to different ES, for instance related to some soil ES (earthworms, spiders, termites, soil macrofauna, plants) or to pollination (Sphingidae)

- their sensitivity to local perturbations (fruit flies)

- their specific response to landscape composition and their migrating abilities (bees, moths and birds).

For each group, we first normalized the species richness as a proportion (0-1) of the highest richness observed (of the same group) in the 135 sampling points (Equation 1). Then, we averaged the normalized richness for each sampling point to calculate the final index of species.

$$
\begin{array}{r}
\left.\left.\left.\left.\operatorname{Index}=\left(\frac{T 1^{i}}{\max (T 1)}\right)+\frac{T 2^{i}}{\max (T 2)}\right)+\frac{T 3^{i}}{\max (T 3)}\right)+\left(\frac{T 4^{i}}{\max (T 4)}\right)+\frac{T 5^{i}}{\max (T 5)}\right)+\frac{T 6^{i}}{\max (T 6)}\right)+ \\
\left.\left.\left.\left.\frac{T 7^{i}}{\max (T 7)}\right)+\frac{T 8^{i}}{\max (T 8)}\right)+\frac{T 9^{i}}{\max (T 9)}\right)+\frac{T 10^{i}}{\max (T 10)}\right)
\end{array}
$$

With $T_{1}, \ldots T_{9}$ : taxa used for the calculations $\operatorname{Max}(T)$ : maximal value for the considered taxa

Equation 1: Formula used to calculate the biodiversity index 


\section{$\underline{\text { Richness of pollinators }}$}

Pollination is considered in the MEA as a regulatory service (MEA, 2005) and corresponds to the interaction between plants and pollinators. Since the characteristics of the species (trophic regimes for example) are very different within a taxonomic group, it is difficult to associate the supply of the same ES to all the species of one group. Thus, it had been considered more appropriate to work at the level of taxonomic groups for which almost all species provide a service. We decided to take the specific richness of Sphingidae moths as an indicator of the pollination service because most organisms of this species are pollinators. It is recognized that they account for $5 \%$ to $10 \%$ of the pollination in tropical forests (Oliveira et al. 2004, Primo 2008).

All Sphingidae moths were collected by light trapping at a single point of each transect, following the methodology described in Lamarre et al., (2015). We chose the point at the location closest to the largest forest present in the agricultural zone. The moths were attracted by a $175 \mathrm{~W}$ mercury vapor bulb - powered by a small portable generator. A white sheet $2 \mathrm{~m}$ high x $3 \mathrm{~m}$ wide was used as a reflector. At each point, the collection was carried out over a single night, from 18:00 to 06:00. Collected as soon as they arrived on the leaf, the moths were then killed by injection of ammonia, stored and dried in marked paper envelopes, and taken to the lab for identification and enumeration. We used the resulting number of the enumeration as a variable for the pollination service.

\section{$\underline{\text { Soil chemical quality index }}$}

Support of primary production is one supporting ES, according to the MEA categories. Since the 
role of soil fertility as an indicator of primary production has been emphasized by the MEA (MEA, 2005), we primary production support through an indicator of soil fertility: an index of soil chemical quality.

The index was calculated using particle-size distribution and chemical properties of the $0-10 \mathrm{~cm}$ soil horizon that were measured from a composite from two pits.

A Principal Components Analysis (PCA) was performed on several soil chemical proprieties (pH $\mathrm{H}_{2} \mathrm{O}$, cation exchange capacity $-\mathrm{CEC}$ - at soil $\mathrm{pH}$; exchangeable $\mathrm{Al}_{3}{ }^{+}, \mathrm{Ca}_{2}{ }^{+}, \mathrm{Mg}_{2}{ }^{+}$and $\mathrm{K}^{+}$; exchangeable $\mathrm{N}_{4}^{+}$and extractable P - Velasquez et al., 2007), measured using standard methods (Pansu and Gautheyrou, 2006). The soil chemical quality index was determined from this PCA.

\section{Water available for plant}

Water regulation is considered as a regulation ES. It is highly dependent on the volume of water retained or stored in the ground. The water regulation ES has therefore been studied through the volume of water available for plants.

Measurement of soil storage capacity (i.e. height) of plant-available water in the $0-10 \mathrm{~cm}$ soil horizon followed a specific sampling protocol: cores with undisturbed structure (cylinders of 100 $\mathrm{cm}^{3}$ ) in the $0-10 \mathrm{~cm}$ horizon (four replicates) were taken from one of the five points on each farm, chosen so that the main land use types were sampled in each area proportional to their occurrence. From laboratory measurements with a pressure-plate apparatus (Pansu and Gautheyrou, 2006) for 27 points (108 cores), multiple-linear-regression models were generated to estimate, from the simplest soil variables measured at all points (clay, silt and sand contents, bulk densities (qb), vertical resistance (Rv) of the superficial horizon measured with a cone penetrometer, $\mathrm{pH}, \mathrm{CEC}$ and $\mathrm{C}$ content), the water retention capacities at different water 
potentials. Plant-available water capacity was then calculated as the water volume drained between matrix potentials of $-30 \mathrm{kPa}$ and $-16 \mathrm{MPa}$.

\section{$\underline{\text { Soil carbon stocks }}$}

Soil carbon stocks are an indicator of the soil chemical fertility. It thus can be considered as an indicator of the supporting ES "support to primary production".

Soil carbon stocks were calculated from bulk density measurements in the $0-30 \mathrm{~cm}$ horizon (CHNS analyzer in three samples from each plot).

\section{$\underline{\text { Rate of water infiltration into the soil }}$}

Rate of water infiltration into the soil is an indicator erosion control, a regulating ES. By infiltration capacity soil, surface water run-off can be prevented or limited, reducing the risks of upstream erosion and downstream flooding (Zimmerman et al., 2006)

Rate of water infiltration into the soil was measured on the field, using a Beerkan infiltration test

from a fixed water volume of $250 \mathrm{~cm}^{3}$ poured into a $20 \mathrm{~cm}$ diameter simple ring inserted at the soil surface to a depth of approximately $1 \mathrm{~cm}$.

\section{$\underline{\text { Vegetation carbon stocks }}$}

Climate regulation is a regulatory service, according to the MEA classification. Forested ecosystems, through their ability to store carbon, play an important role in mitigating climate change. As such, we studied the service of climate regulation on the basis of an indicator: vegetation carbon stocks.

Samples were made for plots of $50 \times 10 \mathrm{~m}^{2}$ for forests and $50 \times 5 \mathrm{~m}^{2}$ for fallows. First, after 
identifying vegetation species, the diameter and height of individuals and water content at $70^{\circ} \mathrm{C}$ of corresponding biomass aliquots (all individuals with $\mathrm{dbh}<5 \mathrm{~cm}$ ) were measured. Then, allometric equations were implemented to estimate aboveground dry plant biomass for forests (Gerwing, 2002) and fallows (Nelson et al., 1999). In the case of individual with $\mathrm{dbh}>5 \mathrm{~cm}$, the factor 0.603 was applied and in the absence of carbon analysis of plant samples, a factor of 0.5 was used (Markewitz et al., 2004).

\subsubsection{Remote sensing data: explanatory variables}

To map ES indicators, we applied spatial extrapolations uniting the plot-level measures with local high-resolution satellite imagery (Table 2). The studied ES indicators were strongly related to environmental conditions, explanatory variables were chosen to characterize different aspects of the landscape. Thus, we used remote sensing data that give information about vegetation cover (e.g. land cover, vegetation density) and topography (e.g. elevation, slope). They were derived from the processing of the 1990, 1994, 1996, 2001 and 2007 Landsat TM images (30 x $30 \mathrm{~m}$ spatial resolution) carried out under ENVI and the processing of the Aster Digital Elevation Model (DEM - 30 x 30 m spatial resolution). These data were known for all three study sites. All the spatial data obtained by remote sensing were extracted for the 135 sampling points.

Landsat images were radiometrically and geometrically corrected prior to classification to ensure comparability across Pará. The Landsat classifications were produced by supervised maximumlikelihood classifications of six land-cover classes (forest, burned forest, juquira-capoeira [fallow lands], grasslands with trees, clean grasslands and bare soils) for 2007. Training data used for the supervised classification were sampled during field campaigns using a GPS. In addition, analysis 
and processing of land cover classification were also extended to all Landsat TM images of the dataset (from 1986 to 2007). Thus, from the land-use maps obtained for the four dates, five classes of land-use trajectories were determined (Oszwald et al., 2012), from a homogeneous forest structure (class 1) to an agricultural dynamic of extensive breeding (class 5). Landsat TM images were also use to calculate two vegetation indexes giving information about vegetation density (NDVI) and water content into plants (NDWI). Finally, we calculated the distance to each pixel to the closest forest patch (in meters).

The topography data informed the elevation (in meters) at every point. Slopes synthesized the altitude difference between two adjacent pixels and were provided as a percentage. These two variables were quantitative and were treated as continuous raw data. The "topography" variable corresponded to a synthetic characterization of the topographic context comprising four modalities: bottom of valleys, hilltops, zones of steep slopes and zones of low slopes. Finally, we deduced from the DEM the hydrographic network and then to determine a distance to the rivers ( 0 to 100 meters, 100 to 200 meters, 200 to 300 meters, 300 to 500 meters and more than 500 meters). The size of the watercourses was not taken into account since there was no difference in size between the rivers in the study area.

We also used a variable, named "Site" that corresponded to the identity of the study site to which each pixel belonged.

Table 2

\subsection{Regression methods}

\subsubsection{General principle}

From a statistical point of view, the approach consisted in the implementation, for each ES 
indicator, of two regression methods (Figure 2). Regression methods aimed to explain the relation of variable (an ES indicator) with other variables, described as explanatory (geographic data obtained by remote sensing). Through variable-selection procedures, we selected only the significant explanatory variables. From a statistical point of view, such procedures were necessary to get the smallest model that fitted the data and to avoid noise and collinearity. From a thematic point of view, they were necessary to identify the components of the landscape that impact the ES supply and how they impacted. Once the method was built on the available data (135 sampling points - field data and remote-sensing data extracted for these 135 sampling points), it was applied to the entire study sites, to predict the variable of interest from new observations collected on explanatory variables only (pixels).

\section{Figure 2}

These regression methods were then used to predict the values of ES indicators only from the remote-sensing data. We had two objectives for using the statistical methods. First, we wished to explain the variations observed in each indicator. Applying a statistical method meant impartially selecting factors, the control factors, that significantly influence the ecological bioprocesses. Second, we wished to predict values of ES indicators for entire areas to develop ES indicator maps from sampling data. Two regression methods were selected to predict quantitative variables from categorical and quantitative variables: multiple linear regression (Cornillon and Matzner, 2011) and regression trees (Classification And Regression Trees (CART) algorithm - Breiman, 1984). We chose these two methods among others because (1) both are regression methods and they can be used to get predictions; (2) both could deal with qualitative and quantitative data and (3) however, since one is parametric and the other is not, they are based on two different 
modeling principles. To implement the cross validation procedures, the original dataset was split into a learning sample on which each model was built and of a test sample on which the model was applied to predict the ES values. A prediction error was calculated for each by averaging the mean squared differences between predictions and observed values on the whole test sample. This allowed the comparison between the predictive properties of each regression method. To facilitate the interpretation, the scores were standardized (for each indicator, the two scores were divided by the maximal value).

\subsubsection{Maps validation}

Maps validations were based on a confrontation between the ES observed values (135 sampling points) and the values predicted by the models.

For comparative purposes, cross-validation procedure (cumulated prevision error) is more reliable than $\mathrm{R}^{2}$, which automatically increases with the number of explanatory variables. We then used the cross-validation score to determine the best methodology for each indicator. To perform cross-validation procedure, we split the original dataset (135 points) into a learning sample on which each model was constructed and a test sample on which the model was applied to predict new ES values (Refaeilzadeh et al., 2009). From a total of 100 replays, a mean square error measuring the difference between the predicted values on the test sample and the values observed in the field was calculated for each model. In the procedure, about $90 \%$ of the individuals (around 120 individuals), were randomly selected to form the learning sample.

Once the predictive properties of both methods had been compared through data splitting (cross validation) procedures, ES maps were built using the chosen model. Then computing the $\mathrm{R}^{2}$ 
yields a convenient way of interpreting the reliability of the resulting maps. Indeed the more the $\mathrm{R}^{2}$ are close to 1 the closer the ajusted values are to the original data (Cornillon and MatznerLober, 2011). Thus computing $\mathrm{R}^{2}$ on a final map gave a measure of its goodness of fit. However, the $\mathrm{R}^{2}$ could neither be used as a variable selection procedure (adding variables automatically increases the R2 so using this criteria would always lead to keep all the variables) nor as a criteria to compare the regression methods (goodness of fit should not be confused with predictive properties.

\section{Results}

\subsection{General statistical results}

The statistical models were generally reliable (e.g., $\mathrm{R}^{2}=0.65$ for the biodiversity index and 0.67 for the soil chemical quality index; Table 3$)$. Results differed greatly among indicators $\left(\mathrm{R}^{2}\right.$ varying from 0.39 for water available for plants to 0.75 for vegetation carbon stocks). Consequently, we decided to map only indicators with $\mathrm{R}^{2}>0.50$. Four indicators were predicted with regression trees: the biodiversity index, richness of pollinators, soil carbon stocks and soil

chemical quality. The other two indicators (vegetation carbon stocks and rate of water infiltration into the soil) were predicted with linear models.

Table 3

Besides variability in their ability to predict a given indictor, models sometimes differed greatly 
in the number and nature of variables selected (Table 4 - The variable written in bold characters correspond to the most significant variable). However, we could notice two general trends: first, in general, a large number of variables were selected, around 5 on average, underlying the complexity of the phenomena studied. Second, for five of the six models, "site" was selected as a categorical variable.

Table 4

\subsection{ES indicator maps}

\subsubsection{Influence of the general location}

Spatially, the index differed greatly among sites for most of the six mapped indicators, such as the biodiversity index (Figure 3, C and D), richness in pollinators (Figure 4B, C and D), soil chemical quality (Figure 5B, C and D), soil carbon stocks (Figure 6B, C and D) and vegetation carbon stocks (Figure 8B, C and D). For instance, biodiversity index and richness in pollinators were generally higher in Maçaranduba than in the two other sites (Figures 3 and 4). This site effect could be the result of multiple factors, such as the diversity of pedological characteristics, public policies and local socio-economic context, differences in the vegetation state.

Figures 3 to 8

\subsubsection{Influence of land-cover characteristics}


The influence of land cover characteristics depended on three main factors: (1) the land cover, (2) its changes and (3) the landscape configuration. (1) Most ES indicator maps showed the influence of land-cover changes on ES supply (e.g., for biodiversity index, richness of pollinators (Maçaranduba), soil chemical quality index, rate of water infiltration into the soil and vegetation carbon stocks, Figures 3-8). For four of these indicators (biodiversity index, richness of pollinators, rate of water infiltration into the soil and vegetation carbon stocks), the highest values were located in forested areas, with the lowest values in deforested areas: farms and riversides in Maçaranduba, the main road in Pacajá, and the southern part of Palmares II close to the city, influenced by the railway and the road. Maps of soil chemical quality index showed opposite trends: soil in forested areas was chemically poor, and slash-and-burn agriculture, along with the decrease in forest nutrient recycling, improved soil chemical quality (Grimaldi et al., 2014). Contrasts within the forest and pasture areas were due to certain topographical effects (Figure 5B, $\mathrm{C}$ and D). For example, if the highest vegetation carbon stocks were located in the most forested areas (preserved forests and, to a lesser extent, burned forests) in the three sites (Figure $8 \mathrm{~A}, \mathrm{~B}$ and C), the highest stocks in Palmares II were lower than those in the two other sites (Figure 8). Indeed, carbon storage depended on the state of the vegetation. Forests in Palmares II, which were highly degraded, store less carbon than forests in the other sites. (2) Some regression models and maps also highlighted the crucial role of land cover changes across in ES supply, through the influence of the variable "historical trajectory of land cover". For instance, the maps of soil infiltrability showed contrasting homogeneous patches of the ES supply (Figure 8). At the three study sites, areas of high infiltrability indeed contrasted with those of low infiltrability, such as riversides in Maçaranduba (Figure 7.A), the deforestation front in Pacajá (Figure 7.B) and the southern part of Palmares II (Figure 7.C). In other words, the rate of water infiltration into the soil was lowest in the areas that had been deforested the longest. (3) Some differences in the ES 
supply, especially among the three sites, could also reflect the influence of landscape configuration. For instance, in Maçaranduba, contrasts between high richness and low richness in Sphingidae moths were due to sharp contrasts in the landscape, between large areas of preserved forests and pastures. At the other two sites, differentiation between land covers was less clear: since Pacajá was colonized, a landscape gradient is evolving. In Palmares II, forests were highly degraded and residual, and pastures were abandoned then transformed into fallow lands. Consequently, at these two sites, continuity in land-cover types existed, leading to an absence of statistical and spatial contrasts in biodiversity and richness of pollinators.

To better understand the role of land cover changes in ES supply, we performed analyses of variance (ANOVA) on the plot data to analyze the differences in ES values among land cover classes. For some indicators (Biodiversity index, index of soil chemical quality, rate of water infiltration into soil and vegetation carbon stocks), the analyses were significant. Some boxplots provided an overview of the contribution of different areas in providing ES (figure 3), highlighting that land cover changes impacted most of the indicators. The boxplots underlined the presence of a gradient from forests where ES supply was globally high to pastured and cultivated areas where ES supply was globally low. This transition from forest to pastured or cultivated areas resulted in a gradual decline in the vegetation carbon stocks and in the rate of water infiltration into oil. It also caused an enrichment of the soil chemical quality.

Figure 9

However the analyses were not significant for the two indicators: richness in Sphingidae and soil 
carbon stocks. It was then necessary to study and map our indicator with other data than the land cover classification sole. As a matter of fact, most regressions also emphasized the influence of other factors such as topographical factors and the general location (site effect). For instance, the biodiversity-related indicators were very impacted by the general location, the topography, and to a lesser extent, slope, vegetation density and its water contents, elevation and historical landcover trajectory.

\subsubsection{Influence of the other factors}

The regression models underlined the role of inherent proprieties of the ecosystem in ES supply, such as the elevation or the slope. Moreover, the site effect previously identified could reflect the influence of such factors. For instance, soil carbon stocks were higher in Palmares II than in the two other sites, because of the soil nature. Indeed, these two last sites had a large amount of hydromorphic soils. Areas that stocked the most carbon in the soil had temporally stable land cover (forests and old pastures), especially in areas of dense vegetation. In Pacajá and Maçaranduba, stocks were lower due to the nature of the soils. Morphologically, water stagnated in these soils during the rainy season, leading to a deficit or absence of oxygen. In these soils, crystallization (transformation of $\mathrm{CO}_{2}$ ), took more time.

\section{Discussion}

In this paper, we participated to the improvement of scientific knowledge about the impacts of deforestation activities. To do so, we identified factors of control of a large set of ES indicators and developed maps of these indicators. The resulting maps showed variations in ES supply in a context of deforestation front and enable better understanding of environmental challenges in 
these areas. For example, most of the maps presented highlighted a site effect. This meant that the study site where the sampling was made is important in terms of the ES supply: for instance, carbon stocks in the forests of Palmares II were globally lower than carbon stocks in the forests of Maçaranduba and Pacajá. This site effect illustrated three potential factors:

- the environmental specificities of each study site, e.g. the soil of the three sites were globally very different,

- historical depth of the deforestation process. Pacajá, as the site with the most recent deforestation processes, presented globally higher ES supply than the two other sites

- the specific socio-political context of the study site.

Furthermore, the analyses illustrated the influence of land-cover changes on ES supply in a deforestation context (Figure 10): in Maçaranduba, ES supply was structured by the distance to the main river, in Palmares II by the railway and the distance to city centers, and in Pacajá by the main road. These three elements constituted the main historical and current elements of deforestation. Forests could be distinguished from cultivated or deforested areas because of their relatively high levels of ES supply (except for the soil chemical index - Grimaldi et al., 2014). Within areas of human influence, transition areas (burned forests and fallow lands) provided an intermediate level of ES. Indeed, trees emit carbon when burning (Dixon et al., 1994). Moreover, roots and leaves decrease the impact of raindrops on the ground, which reduces soil infiltrability (Zimmerman et al., 2006). In cultivated areas, transformations due to human activities have been experienced more intensively and for a longer time. This has led to degradation of most of the services through the loss of forest and exposure of the areas to climatic and other human factors. However, even though land-cover changes have a crucial influence on ES supply, other factors 
were important, such as topography (Dominati et al., 2010; Grimaldi et al., 2014). Yet, such factors often miss in ES mapping procedures (Troy et Wilson, 2006; Fang et al., 2014). Some indicators of ES supply (soil carbon stocks and richness in Sphingidae) ae not impacted, or very little, by land cover changes. This underlines limitations in the use of lookup tables approaches to map ES (Sumarga et Hein, 2014); when specific values for an ES are attributed to every pixel in a certain land cover class.

Figure 10

Besides this thematic dimension, our work was also an opportunity to lead a reflection on issues and challenges in ES mapping. In this sense, we highlighted significant benefits in ES mapping processes and the contributions of statistical methods to characterize the spatial distribution of ES supply. The use of remote-sensing and GIS tools can produce indicators describing ES at any point in a region, which helps implementing ES concept by giving information about the environment state of a location. The utility of mapping ES is partly based on the applicability of the concept for policymakers, but also for local people (Oszwald et al. 2011). Although margins of error, inherent in the mapping processes itself such as data sampling, modeling processes, may exist, ES mapping is an essential tool for local actors, who can appropriate the ES and effectively develop territories by adapting management practices to local characteristics and public policies. The potential offered by ES mapping is attractive for implementing public policies that aim to restore habitat or protect certain ES. They are also attractive for identifying territories currently influenced by human dynamics and in which protective policies are underway (Burkhard et al., 2010; Burkhard et al., 2012; Nemec et al., 2013). Development of these mapping approaches 
seems to facilitate actions or encourage the development of new regionalized legislation to promote the protection of ES (Hervé-Fournereau, 2012). As margins of error exist, it seems essential to make explicit the level of the map's uncertainty. For that reason, we systematically associated a $\mathrm{R}^{2}$ to each map and a map of residuals of the model, so giving information about the reliability of each ES map.

Despite these significant benefits of specific tools such as remote sensing, statistics or GIS to map ES, our results also demonstrated the complexity of the mapping processes. Firstly, the previously exposed site effect highlights the importance of the local scale when mapping ES, to take local characteristics into account. In this sense, land-management decisions are often associated with local studies (Van der Biest et al., 2014). For operational purposes, it can actually be a burden to map ES at larger scales, even though these larger scales can be very useful, especially to inform societies about the importance of ES (Van der Biest et al., 2014). However, even if we proposed here a highly reproductible methodology, this site effect implies also that the regressions used in this study to map indicators of ES supply cannot be applied elsewhere. New modelling (model selection) should be done for any case study. In addition to that, the remote sensing data we used are free and worldwide available but our approach implies the availability of field data that could be a limitation for a reproductibility of the methodology. Secondly, the variations of the $\mathrm{R}^{2}$ from one indicator to another highlighted limits to model certain ES indicators from remote-sensing data. Variations in certain indicators, such as vegetation carbon stocks, can be mostly or entirely explained by modified properties of ecosystems, such land cover changes, that respond to management. These properties can be partly explained using remotesensing data. Some indicators, however, such as water available for plants, could be greatly 
influenced by inherent ecosystem properties. Unfortunately, these properties can rarely be inferred from remote-sensing data (Dominati et al., 2010). Thirdly, the large number of selected variables underlined the necessity to use a diverse dataset and to adapt the data to the specific indicators studied while modeling ES indicators. Finally, the presence of the "site" variable in 5 of the final regressions illustrated a site effect that emphasized the influence of political and/or historical context(s) on ES supply. Each study site had specific public policies, a spatially different history of colonization and development of the territory, all of which greatly impacted ES supply.

In a more general way, this paper highlighted the importance of methodological choices inherent in all cartographic practices and that are only now studied in ES mapping communities. The analyses described in this study are based on statistical methods that link field and remotesensing data. Unlike most studies that map ES indicators, which use ecological relations (e.g. USLE - Universal Soil Loss erosion, allometric equations - Nelson et al., 2009; Bai et al., 2011) or economic models (Eigenbrod et al., 2010; Roces-Diaz et al., 2014), statistical methods help identify factors controlling ES and account for the characteristics of the region. The statistical results emphasized three main points:

(1) Remote-sensing data have unequal ability to map ES indicators. The maps are associated with uncertainty, which depends on the ability to predict ES values and varies among indicators. Certain indicators, such as vegetation carbon stocks, are easily modeled, but this is not the case for all indicators, such as water available to plants. The issue of uncertainty can become particularly important when maps aim to support policies and/or when they are used to analyze trade-offs and synergies. 
(2) Models need to be adapted to each indicator. Certain indicators are better modeled with a regression tree and others with a linear model, and the input data can vary according to the ES indicator. Certain indicators, such as water available for plants, are influenced by inherent soil properties (Dominati et al., 2010) and thus cannot be easily modeled from remote-sensing data.

(3) It is important to model with accurate data, especially for land-cover class. Indeed, most of our regressions underlined the different capacity of land cover classes in ES supply. For instance, each land cover class is characterized by a specific vegetation carbon stock; however, accurate classifications are more easily available at local scales (Domaç, 2004; Foody, 2015). Moreover, modeling at a local scale enables data such as land cover, topography, and geology to be collected more easily, since multivariate models seem essential (Chan et al., 2006).

Key to environmental management, ES frequently appear to be neutral and effective (Kull et al., 2015); however, implicit choices must be made to conceptualize and implement ES (e.g. measurement method, spatial scale of analysis). In this way, the concept is eminently political, and its usefulness depends on its purpose and the context in which it is used (Arnauld de Sartre et al., 2014; Kull et al., 2015). This political dimension is not without consequence. Spatial representation (and measurement - Oszwald et al., 2014) of ES determines potential directions for action. For example, ES mapping seems to provide arguments that support political and social decisions.

Since critical mapping approaches have just begun to emerge in the field of ES mapping 
(feedbacks from 2014 and 2015 Ecosystem Services Partnership conferences - Willemen et al., 2015), we have discussed methodological aspects of critical approaches. It has been shown that maps do not faithfully represent reality, but depend on methodological choices during their creation (predicted values, identified spatial structures and uncertainty). But these choices inherent in creating maps are black boxes for policies (Rangan and Kull, 2009). It is essential to better understand the political choices and consequences inherent in the use of ES and to question the extent to which the concept changes our understanding and description of reality. Since the difficulties encountered when mapping ES reflect vagueness in the concept, a critical look at the mapping tool can be seen as a contribution to critical analysis of the concept.

6. Acknowledgements: The authors wish to thank the Institut des Amériques which funded Solen Le Clec'h's PhD scholarship, the European Union which funded the H2020-MSCA-RISE2015 ODYSSEA project (Project Reference: 691053) and the French Agence Nationale de la Recherche wich funded ANR AMAZ, coordinated by P. Lavelle, and ANR AGES, coordinated by X. Arnauld de Sartre. For measurements of biodiversity, we thank Thibaud Decaëns, Marlúcia B. Martins, George G. Brown, Eduardo Dias, Florence Dubs, Gregory Ferreira, Ivaneide S. Furtado, Raphaël Marichal, Danielle Mijka, Izildinha Miranda, Catarina Praxedes, Rodolphe Rougerie, Alex Velasquez and Patrick Lavelle. For measurements of biophysical soil processes, we thank Michel Grimaldi, Maria del Pilar Hurtado, Izildinha de Souza Miranda, William Santos de Assis, Thierry Desjardins, Florence Dubs, Ernesto Guevara, Tâmara Thaiz Santana Lima, Raphaël Marichal, Fernando Michelotti, Danielle Mitja, Norberto Cornejo Noronha, Mariana Nascimento Delgado Oliveira, Bertha Ramirez, Gamaliel Rodriguez, Max Sarrazin, Mário Lopes da Silva Jr, Simão Lindoso de Souza, Elena Velasquez and Patrick Lavelle. 


\section{References}

Arnault de Sartre X., Castro M., Hubert B., and Kull C.. Modernité écologique et services écosystémiques. In Political Ecology des services écosystémiques, pages 31-47. Peter Lang, Bruxelles, 2014.

Arnauld de Sartre X.. Fronts pionniers d'Amazonie. Les dynamiques paysannes au Brésil. Espaces et milieux. CNRS, Paris, France, CNRS Edition, 2006

Bai Y., Ouyang Z., Zheng H., Li X., Zhuang C., and Jiang B.. Modeling soil conservation, 475 water conservation and their tradeoffs: A case study in Beijing. Journal of Environmental Sciences, 24(3): 419426, 2012.

Bai Y., Zhuang C., Ouyang Z., Zheng H., and Jiang B.. Spatial characteristics between biodiversity and ecosystem services in a human-dominated watershed. Ecological Complexity, 8(2): 177183, 2011.

Breiman L., Friedman J., Stone C., and Olsen R.. Classification and regression Trees. Boca Ratoned, Monterey, USA, 1984.

Burkhard B., Kroll F., and Müller F.. Landscapes capacities to provide ecosystem services: a concept for land-cover based assessments. Landscape Online, pages 122, 2010.

Burkhard B., Kroll F., Nedkov S., and Müller F.. Mapping ecosystem service supply, demand and budgets. Ecological Indicators, 21: 1729, 2012.

Busch M., La Notte A., Laporte V., and Erhard M.. Potentials of quantitative and qualitative approaches to assessing ecosystem services. Ecological Indicators, 21: 89103, 2012.

Chan K. M. A., Shaw M. R., Cameron D. R., Underwood E. C., and Daily G. C.. Conservation planning for ecosystem services. Plos Biology, 4(11): 21382152, 2006. 
Cornillon P.-A. and Matzner-Lober E.. Régression avec R. Springer, France, 2011.

Daily G.. Nature's Services: Societal Dependence on Natural Ecosystem. Island Press. Washington DC, 1997.

Daily G. and Matson P.. Ecosystem services: From theory to implementation. Proceedings of the national academy of Sciences of the United States of America, 105(28): 94559456, 2008.

Darvill R. and Lindo Z.. Quantifying and mapping ecosystem service use across stakeholder groups: Implications for conservation with priorities for cultural values. Ecosystem services, $13: 153161,2015$.

Diaz S., Fargione J., Chapin F. S., and Tilman D.. Biodiversity loss threatens human well-being. Plos Biology, 4(8) :13001305, 2006.

Dixon R., Brown S., Houghton R., Solomon A., Trexler M., and Wisniewski J. Carbon pools and flux of global forest ecosystems. Science, (263):185190, 1994.

Domaç A.. Increasing the accuracy of vegetation classification using geology and DEM. Ph.D. thesis, Middle East technical University, Turkey, 2004.

Dominati E., Patterson M., and Mackay A.. A framework for classifying and quantifying the natural capital and ecosystem services of soils. Ecological Economics, 69(9): 18581868, 2010.

Eigenbrod F., Armsworth P. R., Anderson B. J., Heinemeyer A., Gillings S., Roy D. B., Thomas C. D., and Gaston K. J.. The impact of proxy-based methods on mapping the distribution of ecosystem services. Journal of Applied Ecology, 47(2): 377385, 2010.

Evans T., Manire A., de Castro F., Brondizio E., and McCracken S.. A dynamic model of household decision-making and parcel level landcover change in the eastern Amazon. Ecological Modelling, 143(1-2):95113, 2001.

Fang X., Tang G., Li B., and Han R.. Spatial and Temporal Variations of Ecosystem Service Values in Relation to Land Use Pattern in the Loess Plateau of China at Town Scale. Plos One, 
9(10) :e110745, 2014.

Fearnside P. M.. Deforestation in Brazilian Amazon: history, rates, and consequences. Conservation Biology, 19(3):680688, 2005.

Fearnside P. M.. Amazon forest maintenance as a source of environmental services. Anais da Academia brasileira de ciencias, 80(1): 101114, 2008.

Fisher B., Turner R. K., Burgess N. D., Swetnam R. D., Green J.,. Green R. E, Kajembe G., Kulindwa K., Lewis S. L., Marchant R., Marshall A. R., Madoe S., Munishi P. K. T., MorseJones S., Mwakalila S., Paavola J., Naidoo R., Ricketts T., Rouget M., Willcock S., White S., and Balmford A.. Measuring, modeling and mapping ecosystem services in the Eastern Arc Mountains of Tanzania. Progress in Physical Geography, 35(5): 595611, 2011.

Food and Agriculture Organization of the United Nations. State of the world's forests, 2012. Food and Agriculture Organization of the United Nations, Rome, 2012.

Foody G.. Valuing map validation: The need for rigorous land cover map accuracy assessment in economic valuations of ecosystem services. Ecological Economics, 111:2328, 2015.

Gerwing J.. Degradation of forests through logging and fire in the eastern Brazilian Forest Ecology and Managements, 2002.

Godar J., Tizado E. J., and Pokorny B.. Who is responsible for deforestation in the Amazon ? A spatially explicit analysis along the Transamazon Highway in Brazil. Forest Ecology and Management, 267: 5873, 2012.

Grêt-Regamey A., Weibel B., Bagstad K. J., Ferrari M., Geneletti D., Klug H., Schirpke U., and Tappeiner U.. On the effects of scale for ecosystem services mapping. Plos One, 9(12): 117, 2014.

Grimaldi M., Oszwald J., Dolédec S., Hurtado M. d. P., de Souza M. I., Arnauld de Sartre X., d. Assis W. S., Castañeda E., Desjardins T., Dubs F., Guevara E., Gond V., Lima T. T. S., Marichal 
R., Michelotti F., Mitja D., Noronha N. C., Delgado Oliveira M. N., Ramirez B., Rodriguez G., Sarrazin M., d. Silva M. L., Costa L. G. S., d. Souza S. L., Veiga I., Velasquez E., and Lavelle P.. Ecosystem services of regulation and support in Amazonian pioneer fronts: searching for landscape drivers. Landscape Ecology, 29(2): 311328, 2014

Heink U. and Kowarik I.. What are indicators ? on the definition of indicators in ecology and environmental planning. Ecological Indicators, $10: 584$ 593, 2010.

Hervé-Fournereau N.. Les PSE à la rencontre des territoires forestiers : un outil de préservation environnemental opportun dans les pays en développement. Colloque L'agriculture et les paiements pour services environnementaux : quels questionnements juridiques, France. 2012.

INPE, Prodes, 2014. Projeto Prodes Monitoramento da floresta Amazônica Brasileira por satélite. http://www.obt.inpe.br/prodes/prodes 1988 2014.htm.

Kienast F., Bolliger J., Potschin M., de Groot R. S., Verburg P. H., Heller I., Wascher D., and Haines-Young R.. Assessing Landscape Functions with Broad-Scale Environmental Data : Insights Gained from a Prototype Development for Europe. Environmental Management, 44(6) :10991120, 2009.

Kull C. A., Arnauld de Sartre X., and Castro-Larranaga M.. The political ecology of ecosystem services. Geoforum, 61: 122134, 2015.

Lamarre G., Mendoza I., Rougerie R., Decaëns T., Hérault B., and Bénéluz F.. Stay out (almost) all night: Contrasting responses in flight activity among tropical moth assemblages. Neotropical Entomology, 44(2): 109115, 2015.

Larrère C. and Larrère R.. Penser et agir avec la nature. Une enquête philosophique. La découverte, France, 2015

Le Clec'h S., Oszwald J., Decaens T., Desjardins T., Dufour S., Grimaldi M., Jégou N., Lavelle P.. Mapping multiple ecosystem services indicators: Toward an objective-oriented approach. 
Ecological Indicators 69:508-521. 2016

Malinga R., Gordon L. J., Jewitt G., and Lindborg R.. Mapping ecosystem services across scales and continents: a review. Ecosystem Services 57: 63, 2015.

Markewitz D., Davidson E., Moutinho P., and Nepstad D.. Nutrient loss and redistribution after forest clearing on a highly weathered soil in Amazonia. Ecological Applications, 14(4,S): S177S199, 2004.

McInerny G. J., Chen M., Freeman R., Gavaghan D., Meyer M., Rowland F., Spiegel halter D. J., Stefaner M., Tessarolo G., and Hortal J.. Information visualisation for science and policy: engaging users and avoiding bias. Trends in Ecology \& Evolution, 29(3): 148157, 2014.

M.E.A. (Millenium Ecosystem Assessment). Ecosystems and human well-being: scenarios. Island Press, 2005.

Metzger M., Rounsevell M., Acosta-Michlik L., Leemans R., and Schröter D.. The vulnerability of ecosystem services to land use change. Agriculture, Ecosystems \& Environment, 114(1):6985, 2006.

Naidoo R. and Ricketts T. H.. Mapping the economic costs and benets of conservation. Plos Biology, 4(11): 21532164, 2006.

Nelson B., Mesquita R., Pereira J., de Souza S., Batista G., and Couto L.. Allometric regressions for improved estimate of secondary forest biomass in the central Amazon Forest. Ecology and Management, 117(1-3):149167, 1999.

Nelson E., Mendoza G., Regetz J., Polasky S., Tallis H., Cameron D., Chan K. M., Daily G. C., Goldstein J., Kareiva P. M., Lonsdorf E., Naidoo R., Ricketts T. H., and Shaw M.. Modeling multiple ecosystem services, biodiversity conservation, commodity production, and tradeoffs at landscape scales. Frontiers in Ecology and the Environment, 7(1):411, 2009.

Nemec K. T. and Raudsepp-Hearne C.. The use of geographic information systems to map and 
assess ecosystem services. Biodiversity and Conservation, 22(1):115, 2013.

OECD. Core environmental indicators. Development measurement and use. Technical report, 2003

Oszwald J., Dufour S., Le Clec'h S., and Rollet A.-J.. La cartographie des services environnementaux : une nouvelle grille de lecture pour évaluer les liens homme/environnement? In Spatialités et modernité : lieux, milieux et territoires, 20 ans du SET, Pau, France, 2011.

Oszwald J., Grimaldi, M., and Dufour S. Des processus biophysiques aux indicateurs de services écosystémiques : l'apport des approches paysagères. In Political Ecology des services écosystémiques, pages 191204. Peter land edition, 2014.

Oszwald J., Arnauld de Sartre X., Decaëns T., Gond V., Grimald i M., Lefebvre A., De Araujo Fretas R. L., Lindoso de Souza S., Marichal R., Veiga I., Velasquez E., and Lavelle P.. Utilisation de la télédétection et de données socio-économiques et écologiques pour comprendre l'impact des dynamiques de l'occupation des sols à Pacajá (Brésil). Revue Française de Photogrammétrie et de Télédétection, 198, 2012

Pagella T. F. and Sinclair F. L.. Development and use of a typology of mapping tools to assess their fitness for supporting management of ecosystem service provision. Landscape Ecology, 29(3): 383399, 2014.

Palomo I., Martín-López B., Potschin M., Haines-Young R. and Montes C.. National Parks, buffer zones and surrounding lands: Mapping ecosystem service flows, Ecosystem Services, 4(1), 104-116, 2013.

Pansu M. and Gautheyrou J.. Handbook of soil analysis. Mineralogical, organic and inorganic methods. 2006.

Rangan H. and Kull C. A.. What makes ecology 'political' ?: rethinking 'scale' in political ecology. Progress in Human Geography, 33 (1) 28-45, 2009 
Roces-Diaz J. V., Diaz-Varela E. R., and Alvarez-Alvarez P.. Analysis of spatial scales for ecosystem services: Application of the lacunarity concept at landscape level in Galicia (NW Spain). Ecological Indicators, 36:495507, 2014.

Sharp R., H. Tallis, Ricketts T., Guerry A., Wood S., Chaplin-Kramer R., Nelson E., Ennaanay D., Wolny S., Olwero N., Vigerstol K., Pennington D., Mendoza G., Aukema J., Foster J., Forrest J., Cameron D., Arkema K., Lonsdorf E., Kennedy C., Verutes G., Kim C., Guannel G., Papenfus M., Toft, J. Marsik M., Bernhardt J., Griffin R., Glowinski K., Chaumont N., Perelman A., Lacayo M., Mandle L., Hamel P., and Vogl A.. InVEST User's Guide. 2014.

Sherrouse B. C., Clement J. M., and Semmens D. J.. A GIS application for assessing, mapping, and quantifying the social values of ecosystem services. Applied Geography, 31(2): 748760, 2011.

Schulp CJE, Burkhard B, Maes J, Van Vliet J, Verburg PH. Uncertainties in Ecosystem Service Maps: A Comparison on the European Scale. PloS ONE 9(10). 2014

Sumarga E. and Hein L.. Mapping Ecosystem Services for Land Use Planning, the Case of Central Kalimantan. Environmental Management, 54(1) :8497, 2014

Théry H. Le Brésil. Armand Colin, Paris, France, 2012

Troy A. and Wilson M.. Mapping ecosystem services: Practical challenges and opportunities in linking GIS and value transfer. Ecological Economics, 2(60):435449, 2006.

Van der Biest K., D'Hondt R., Jacobs S., Landuyt D., Staes J., Goethals P., and Meire P.. EBI: An index for delivery of ecosystem service bundles. Ecological Indicators, 37(A): 252265, 2014.

Velasquez E., Lavelle P., and Andrade M.. GISQ, a multifunctional indicator of soil quality. Soil Biology \& Biochemistry, 39(12): 30663080, 2007.

Villa F., Ceroni M., Bagstad K., Johnson G., and Krivov S.. ARIES (Artificial Intelligence for Ecosystem Services): A new tool for ecosystem services assessment, planning, and valuation. In 
11 Th annual BIOECON conference on economic instruments to enhance the conservation and sustainable use of biodiversity, Conference proceedings. Venice, Italy, 2009.

Willemen L., Burkhard B., Crossman N., Drakou E. G., Palomo I.. Best practices for mapping Ecosystem services. Ecosystem Services, 13(1), 1-5, 2015.

Zimmermann B., Elsenbeer H., and De Moraes J. M.. The influence of land-use changes onsoil hydraulic properties: Implications for runoff generation. Forest Ecology and Management, 222(1-3): 2938, 2006. 
Table 1. Description of the 7 ES indicators modeled in this study

\begin{tabular}{|c|c|c|c|c|}
\hline $\begin{array}{l}\text { Spatial } \\
\text { indicator }\end{array}$ & $\begin{array}{l}\text { Unit or } \\
\text { measurement } \\
\text { range }\end{array}$ & ES provided & $\begin{array}{l}\text { MEA } \\
\text { category }\end{array}$ & $\begin{array}{l}\text { Variables used to } \\
\text { calculate the indicator }\end{array}$ \\
\hline $\begin{array}{l}\text { Biodiversity } \\
\text { index }\end{array}$ & $0.1-1.0$ & $\begin{array}{l}\text { Food web } \\
\text { support }\end{array}$ & Support & $\begin{array}{l}\text { Number of moths, birds, } \\
\text { bees, fruit flies, spiders, } \\
\text { ants, soil macrofauna, } \\
\text { termites, earthworms, and } \\
\text { small, medium and high } \\
\text { plants }\end{array}$ \\
\hline $\begin{array}{l}\text { Richness of } \\
\text { pollinators }\end{array}$ & $\begin{array}{l}\text { Total number of } \\
\text { Sphingidae } \\
\text { collected }\end{array}$ & $\begin{array}{l}\text { Support to } \\
\text { production and } \\
\text { pollination }\end{array}$ & $\begin{array}{l}\text { Support and } \\
\text { regulation }\end{array}$ & Number of Sphingidae \\
\hline $\begin{array}{l}\text { Soil chemical } \\
\text { quality index }\end{array}$ & $0.1-1.0$ & $\begin{array}{l}\text { Support to } \\
\text { production }\end{array}$ & Support & $\begin{array}{l}\text { Exchangeable } \mathrm{Ca}_{2}{ }^{+}, \mathrm{Mg}_{2}{ }^{+}, \\
\mathrm{K}^{+}, \mathrm{Al}_{3}{ }^{+} \text {and } \mathrm{NH}_{4}^{+} \text {, and } \\
\text { extractable } \mathrm{P} \text { contents at a } \\
0-10 \mathrm{~cm} \text { depth }\end{array}$ \\
\hline $\begin{array}{l}\text { Available } \\
\text { water for } \\
\text { plants }\end{array}$ & $\mathrm{cm}$ & $\begin{array}{l}\text { Water } \\
\text { regulation and } \\
\text { support to } \\
\text { primary } \\
\text { production }\end{array}$ & Regulation & $\begin{array}{l}\text { Clay, silt and sand } \\
\text { contents, } \mathrm{qb} \text {, vertical } \\
\text { resistance, } \mathrm{C} \text { content, } \mathrm{pH}, \\
\text { cation } \\
\text { exchange capacity at } 0-10 \\
\text { cm depth }\end{array}$ \\
\hline $\begin{array}{l}\text { Soil carbon } \\
\text { stock }\end{array}$ & $\mathrm{mg} / \mathrm{ha}$ & $\begin{array}{l}\text { Climate } \\
\text { regulation and } \\
\text { support to } \\
\text { production }\end{array}$ & $\begin{array}{l}\text { Support and } \\
\text { regulation }\end{array}$ & $\begin{array}{l}\text { Bulk density and total } \mathrm{C} \\
\text { content at } 0-10,10-20 \text { and } \\
20-30 \mathrm{~cm} \text { depths }\end{array}$ \\
\hline $\begin{array}{l}\text { Rate of water } \\
\text { infiltration into } \\
\text { the soil }\end{array}$ & $\mathrm{mm} / \mathrm{h}$ & $\begin{array}{l}\text { Water cycle } \\
\text { regulation and } \\
\text { soil erosion } \\
\text { control }\end{array}$ & Regulation & Infiltration rate \\
\hline $\begin{array}{l}\text { Vegetation } \\
\text { carbon stock }\end{array}$ & $\mathrm{mg} / \mathrm{ha}$ & $\begin{array}{l}\text { Climate } \\
\text { regulation }\end{array}$ & Regulation & $\begin{array}{l}\text { Aboveground dry biomass } \\
\text { of trees, bushes and } \\
\text { herbaceous plants }\end{array}$ \\
\hline
\end{tabular}

Table 2. Remote sensing data used to model the 7 ES indicators

\begin{tabular}{|l|l|l|}
\hline Data name & Source & Description and unit/range \\
\hline \multirow{2}{*}{ Land cover } & & $\begin{array}{l}\text { Land cover classification }(2007) \\
6 \text { modalities }\end{array}$ \\
$\begin{array}{l}\text { Trajectory of land } \\
\text { cover }\end{array}$ & $\begin{array}{l}\text { Landsat TM } \\
\text { 30x30 spatial } \\
\text { resolution }\end{array}$ & $\begin{array}{l}\text { Historical trajectory of land cover (from 19990, 1994, } \\
1996,2001 \text { and 2007 images) } \\
5 \text { NDVI }\end{array}$ \\
& & $\begin{array}{l}\text { Normalized Difference Vegetation Index } \\
(-1 ; 1)\end{array}$ \\
\cline { 3 - 3 } NDWI & & Normalized Difference Water Index $(-1 ; 1)$ \\
\hline
\end{tabular}




\begin{tabular}{|c|c|c|}
\hline Distance to forest & & Meter (m) \\
\hline Elevation & \multirow{4}{*}{$\begin{array}{l}\text { DEM ASTER } \\
30 \times 30 \mathrm{~m} \text { spatial } \\
\text { resolution }\end{array}$} & Meter (m) \\
\hline Slope & & Percent (\%) \\
\hline Topography & & $\begin{array}{l}\text { Topographical units } \\
4 \text { modalities } \\
\end{array}$ \\
\hline Distance to water & & $\begin{array}{l}\text { Distance to the rivers } \\
5 \text { modalities }\end{array}$ \\
\hline Site & & $\begin{array}{l}\text { Identity of the study site each pixel belongs to. } \\
3 \text { modalities (Maçaranduba, pacaja and Palmares II) }\end{array}$ \\
\hline
\end{tabular}

Table 3. For the seven ES indicators, $R \$^{2}$ and cross-validation scores (CV).

\begin{tabular}{|l|c|c|c|l|l|}
\hline \multicolumn{1}{|c|}{ Indicator } & \multicolumn{2}{|c|}{ Decision tree } & \multicolumn{2}{c|}{ Linear model } & Selected model \\
\hline & $\mathbf{R}^{\mathbf{2}}$ & $\mathbf{C V}$ & $\mathbf{R}^{\mathbf{2}}$ & $\mathbf{C V}$ & \\
\hline Biodiversity index & 0.65 & 0.98 & 0.34 & 1 & Regression tree \\
\hline Pollinators richness & 0.57 & 0.91 & 0.18 & 1 & Regression tree \\
\hline Soil chemical quality index & 0.67 & 0.79 & 0.50 & 1 & Regression tree \\
\hline Available water for plants & 0.55 & 1 & 0.39 & 0.78 & Linear regression \\
\hline Soil carbon stocks & 0.52 & 0.93 & 0.47 & 1 & Regression tree \\
\hline Rates of water infiltration into soil & 0.66 & 1 & 0.57 & 0.86 & Linear regression \\
\hline Vegetation carbon stocks & 0.74 & 1 & 0.75 & 0.92 & Linear regression \\
\hline
\end{tabular}

Table 4. Selected variables for the most reliable method, for each indicator. In bold, the most significant variable.

\begin{tabular}{|c|c|c|c|c|c|c|}
\hline & Biodiversity & Pollinators & $\begin{array}{c}\text { Soil } \\
\text { chemical } \\
\text { quality }\end{array}$ & $\begin{array}{c}\text { Soil } \\
\text { carbon } \\
\text { stock }\end{array}$ & $\begin{array}{c}\text { Rate of water } \\
\text { infiltration } \\
\text { into the soil }\end{array}$ & $\begin{array}{c}\text { Vegetation } \\
\text { carbon stock }\end{array}$ \\
\hline Land cover & $\mathbf{X}$ & $\mathrm{X}$ & $\mathrm{X}$ & $\mathrm{X}$ & $\mathrm{X}$ & $\mathbf{X}$ \\
\hline Topography & $\mathrm{X}$ & $\mathrm{X}$ & $\mathrm{X}$ & $\mathrm{X}$ & & $\mathrm{X}$ \\
\hline Site & $\mathrm{X}$ & $\mathrm{X}$ & $\mathrm{X}$ & & & \\
\hline Slope & $\mathrm{X}$ & $\mathrm{X}$ & & & \\
\hline $\begin{array}{c}\text { Distance to } \\
\text { forest }\end{array}$ & & $\mathrm{X}$ & $\mathrm{X}$ & $\mathrm{X}$ & & \\
\hline $\begin{array}{c}\text { Distance to } \\
\text { water }\end{array}$ & $\mathrm{X}$ & $\mathrm{X}$ & & & & \\
\hline NDVI & $\mathrm{X}$ & $\mathrm{X}$ & $\mathrm{X}$ & $\mathrm{X}$ & & \\
\hline NDWI & $\mathrm{X}$ & & $\mathrm{X}$ & $\mathrm{X}$ & $\mathrm{X}$ & \\
\hline $\begin{array}{c}\text { Land cover } \\
\text { trajectory }\end{array}$ & $\mathrm{X}$ & $\mathrm{X}$ & & & & \\
\hline Elevation & $\mathrm{X}$ & & & & \\
\hline
\end{tabular}




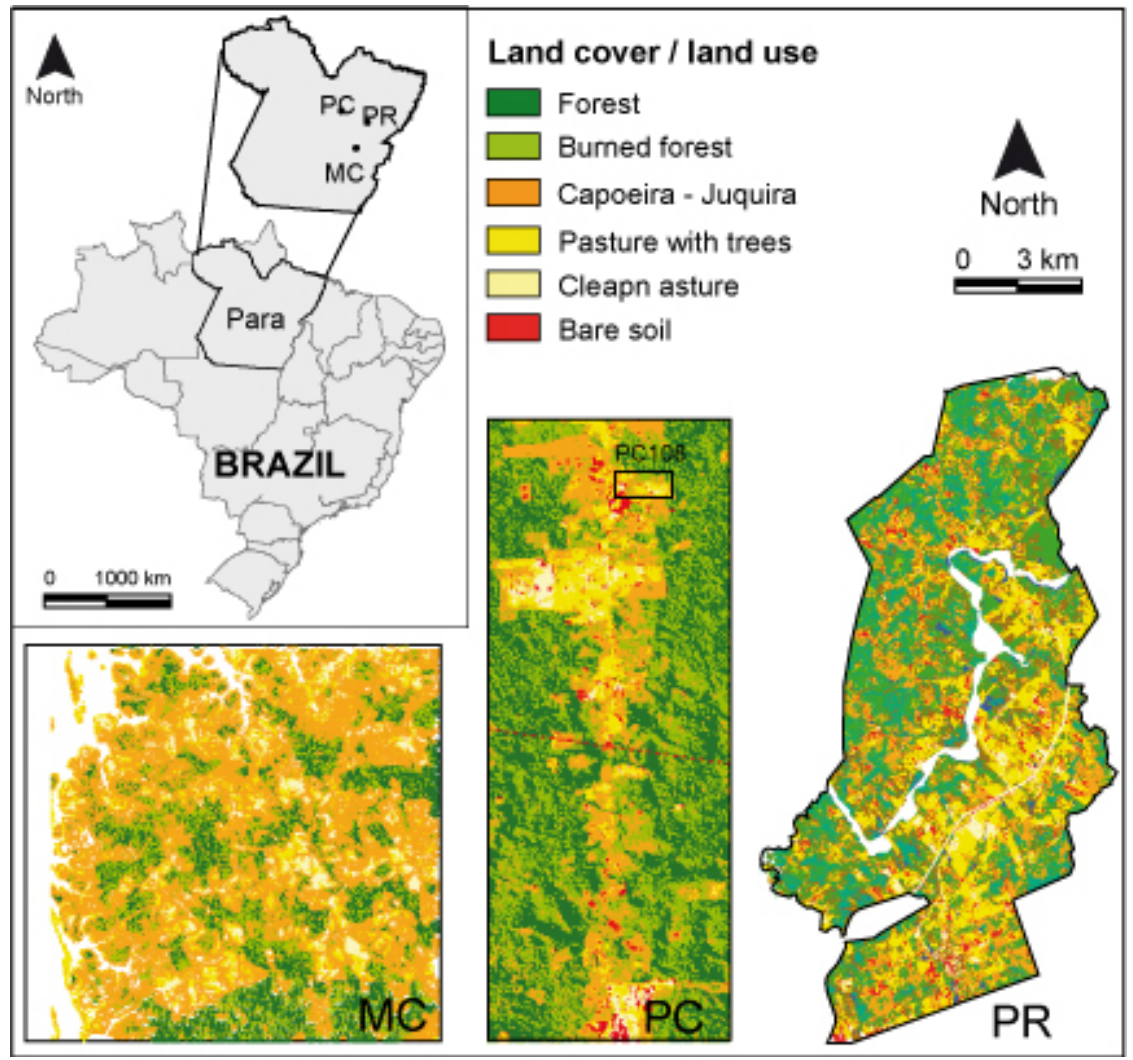

Figure 1. Location of Pará tate and the study sites of Macaranduba (MC), Pacajá (PC), and Palmares II (PR). Colored maps represent land use of the study sites in 2007.

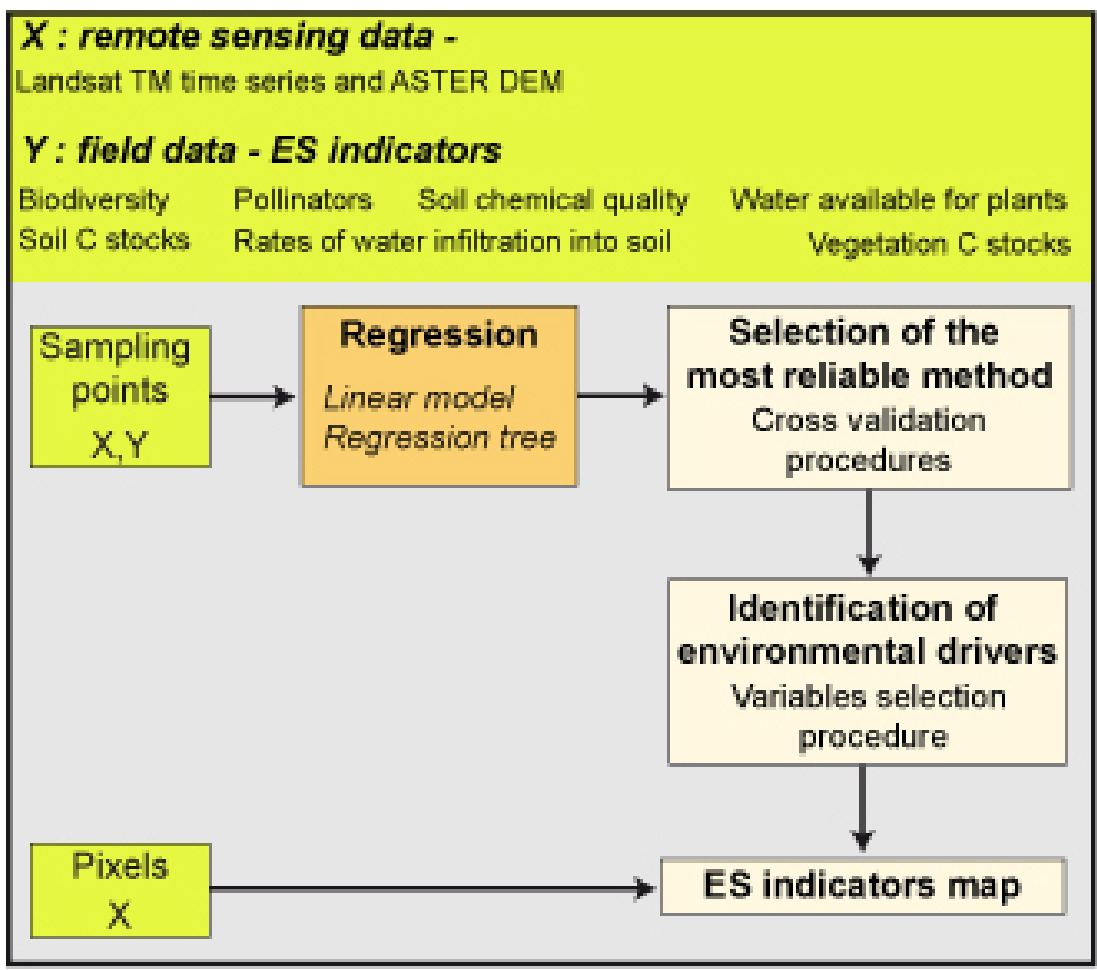

Figure 2. Statistical methodology to map an ecosystem services indicator 


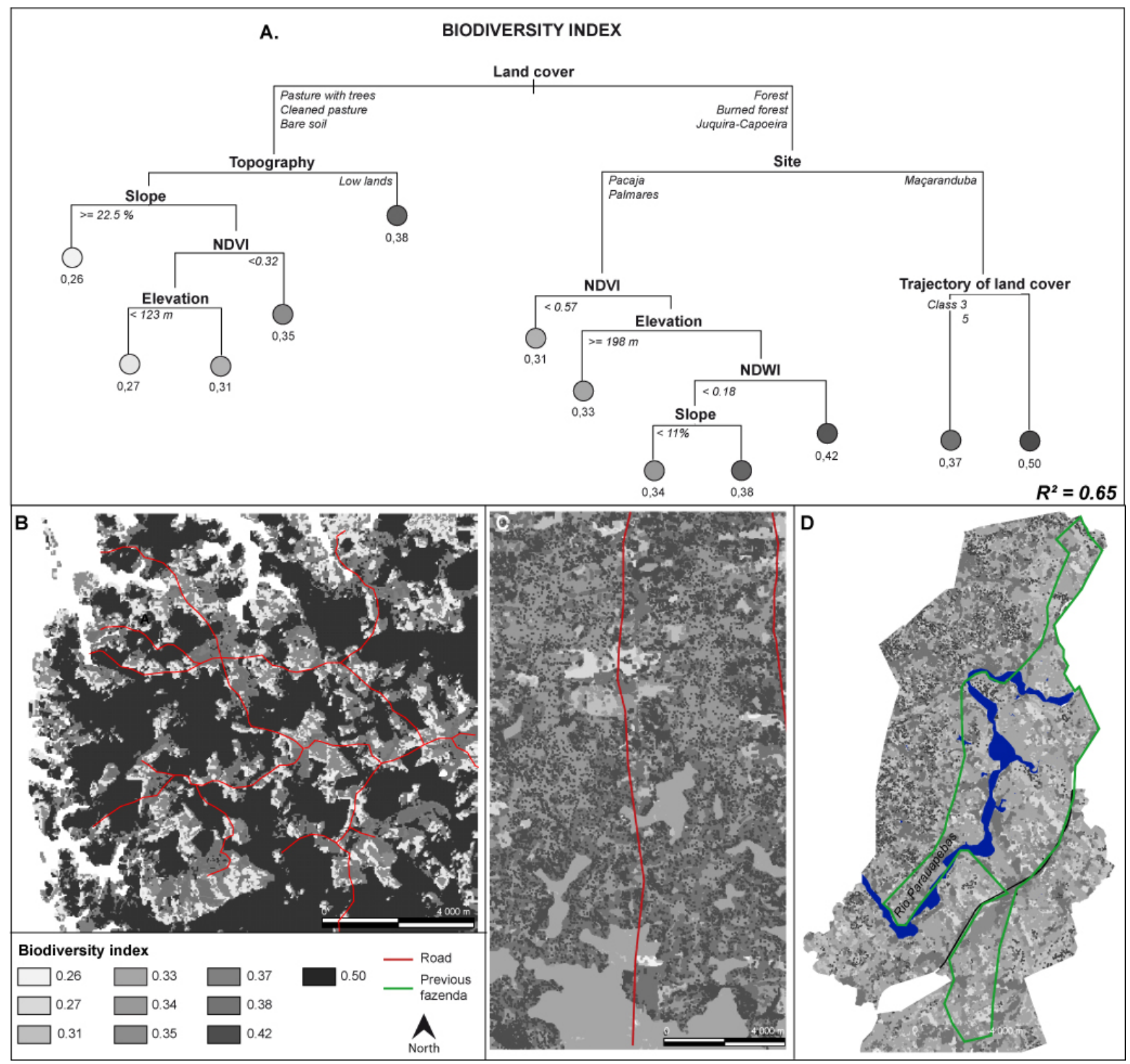

Figure 3. Spatial distribution of the biodiversity index in 2007 in A. Maçaranduba, B. Pacajá and C. Palmares II 


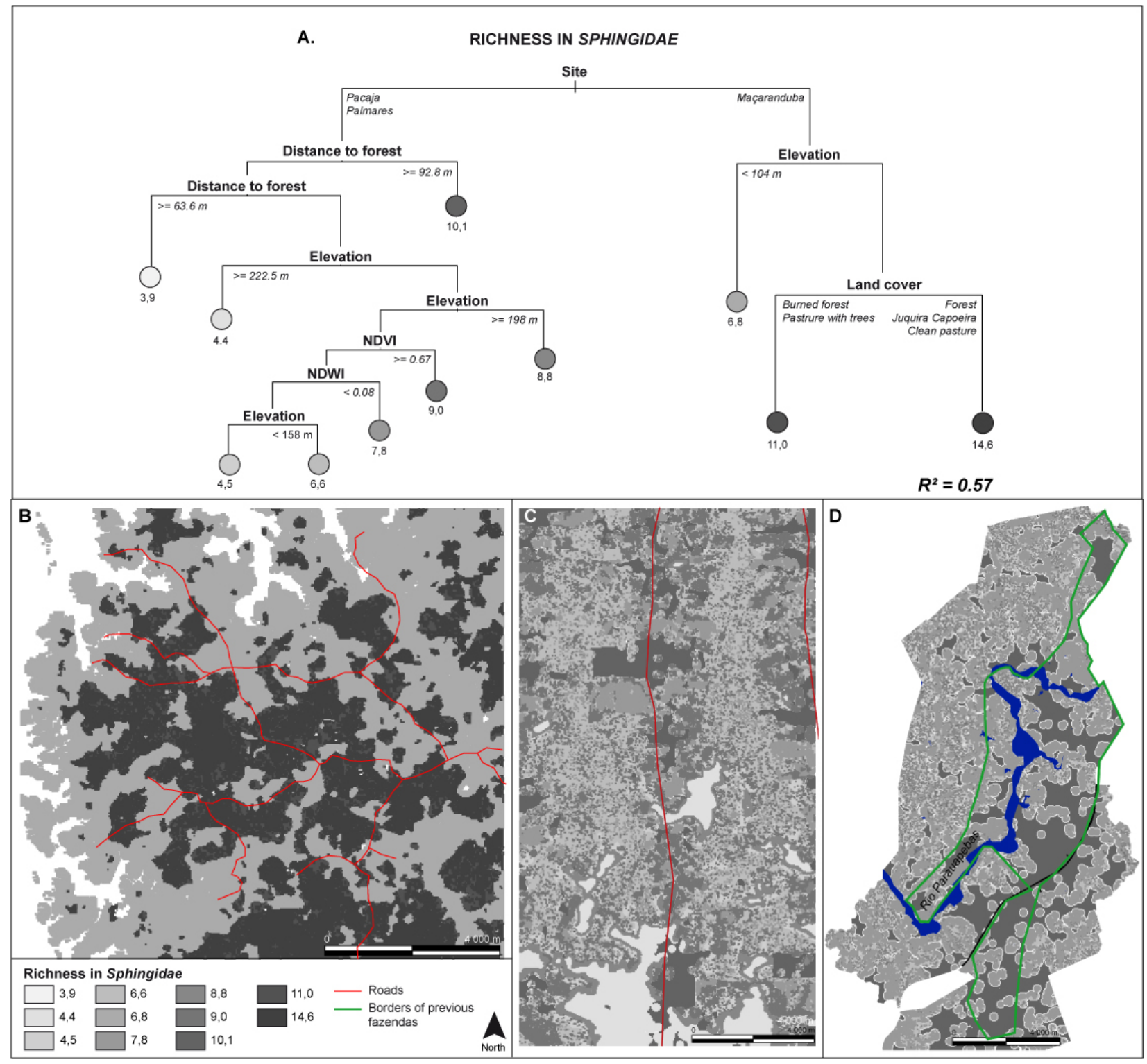

Figure 4. Spatial distribution of pollinators () in 2007 in A. Maçaranduba, B. Pacajá and C. Palmares II 


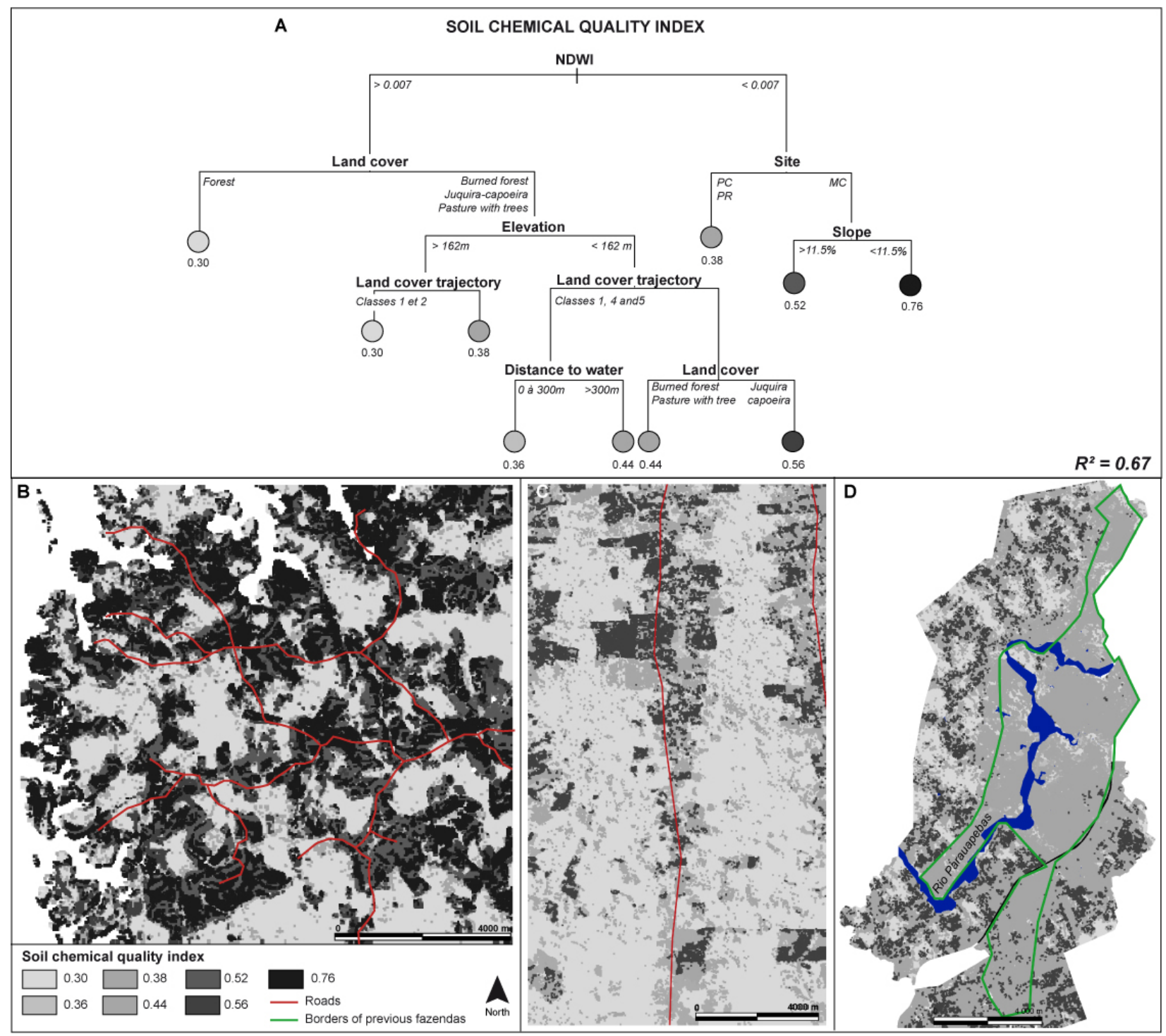

Figure 5. Spatial distribution of the soil chemical quality index in 2007 in A. Maçaranduba, B. Pacajá and C. Palmares II 


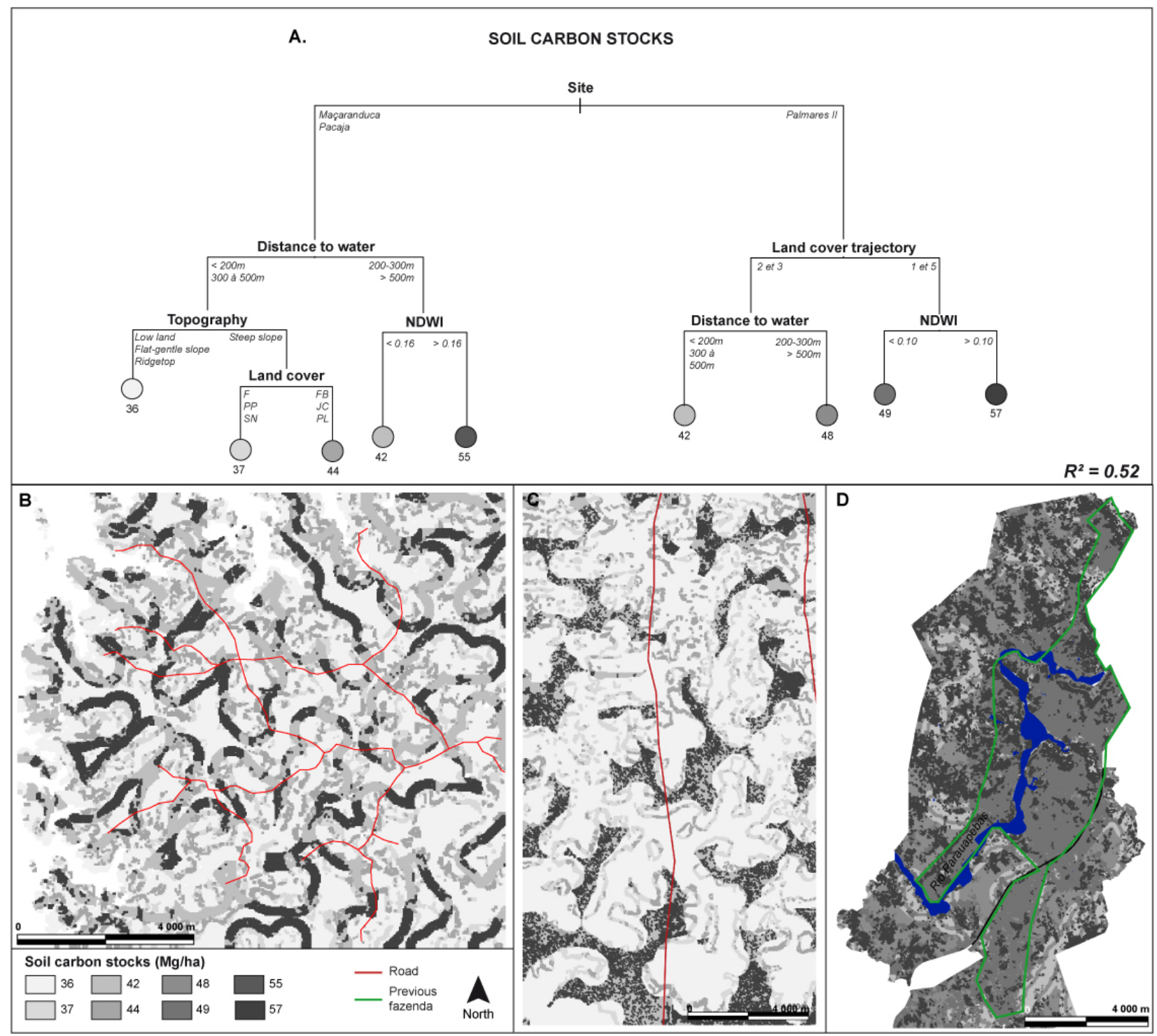

Figure 6. Spatial distribution of soil carbon stocks in 2007 in A. Maçaranduba, B. Pacajá and C. Palmares II 

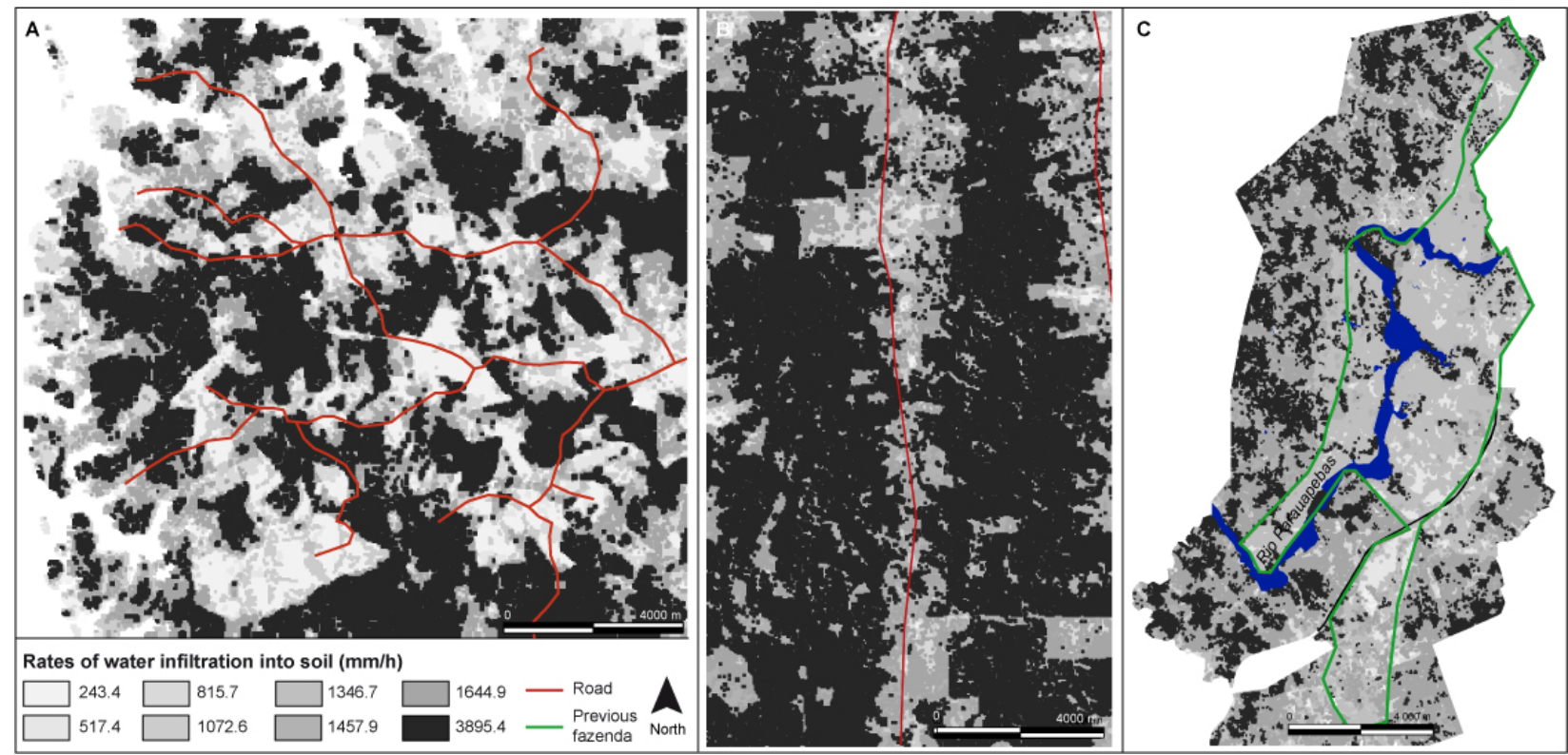

Figure 7. Rates of water infiltration into soil in 2007 in A. Maçaranduba, B. Pacajá and C. Palmares II. More information about the statistical model can be found in supplementary materials
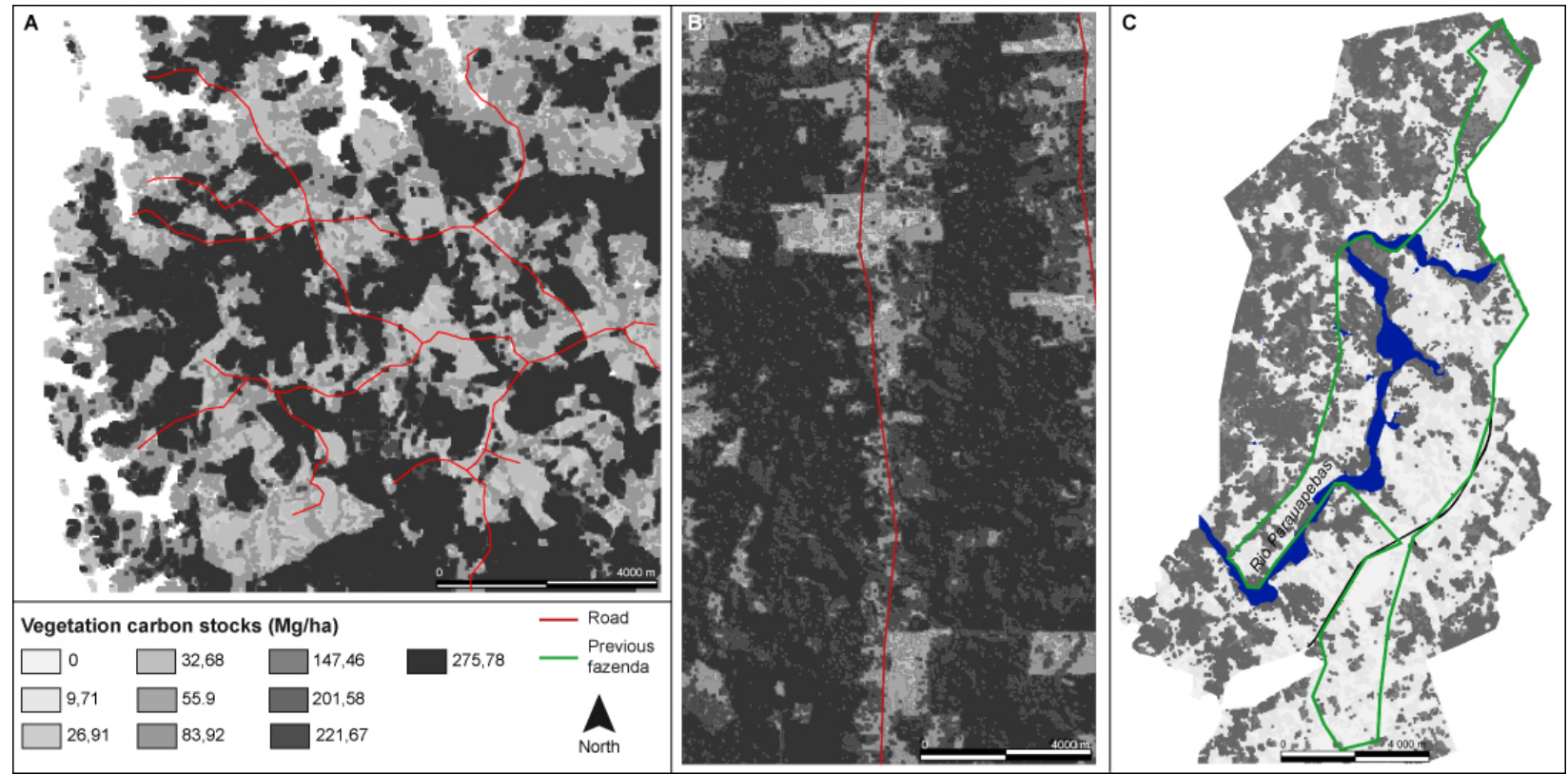

Figure 8. Vegetation carbon stocks in 2007 in A. Maçaranduba, B. Pacajá and C. Palmares II. More information about the statistical model can be found in supplementary materials 


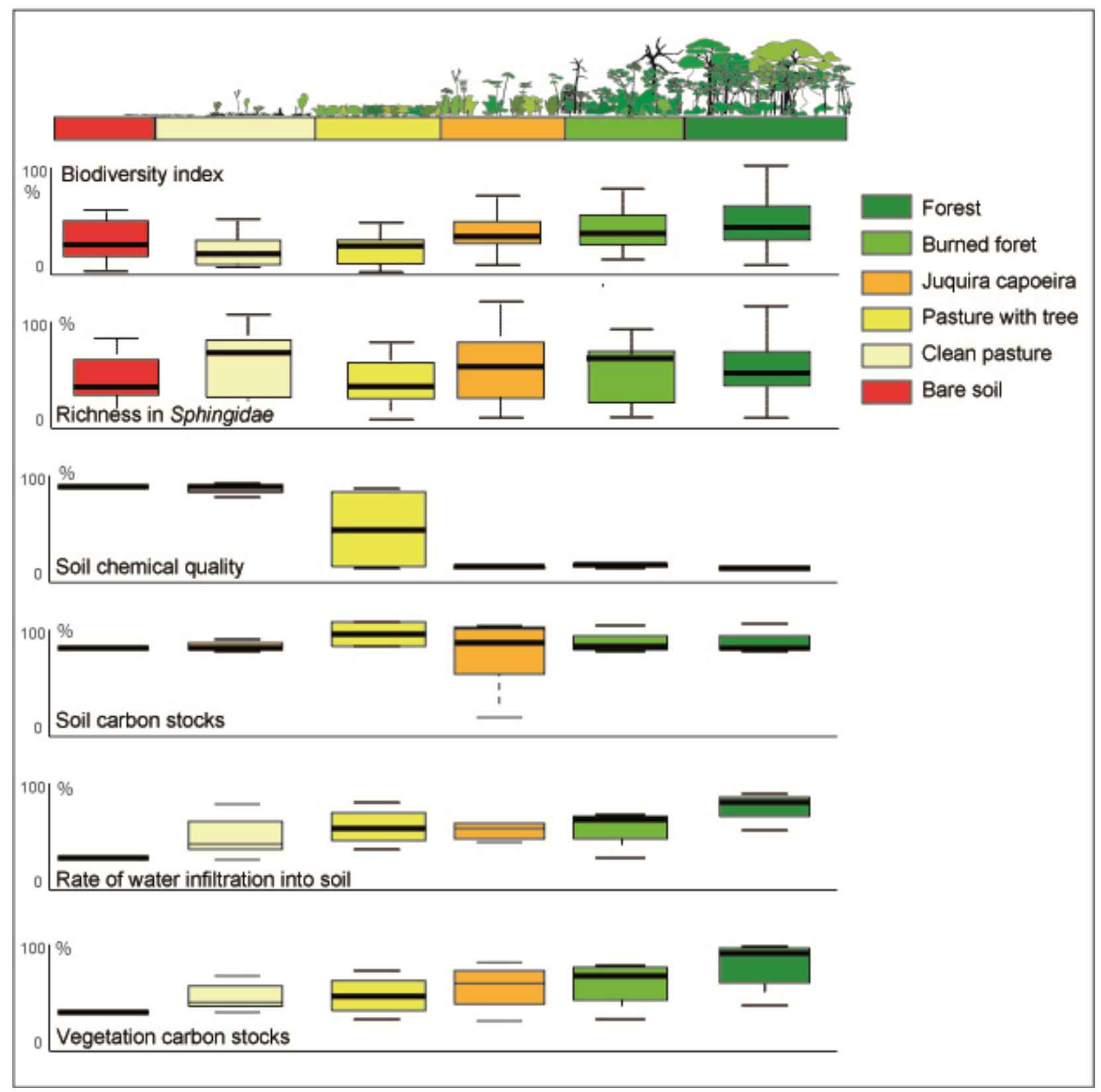

Figure 9. Ecosystem services provided by the six land cover classes. 


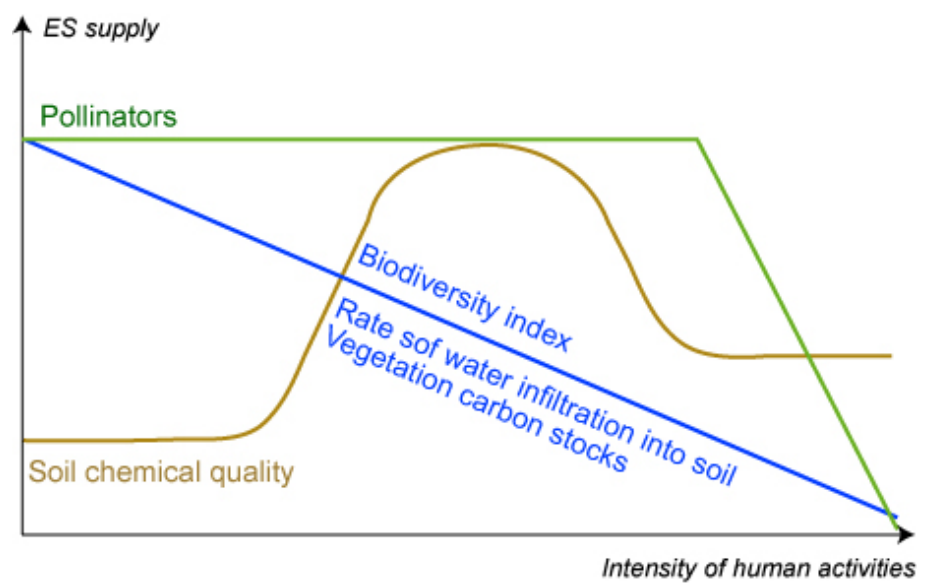

Figure 10. Relation between intensification of human activities and ES supply 